\title{
Chapter 8 \\ Bats and Water: Anthropogenic Alterations Threaten Global Bat Populations
}

\author{
Carmi Korine, Rick Adams, Danilo Russo, Marina Fisher-Phelps \\ and David Jacobs
}

\begin{abstract}
Natural bodies of open water in desert landscapes, such as springs and ephemeral pools, and the plant-life they support, are important resources for the survival of animals in hyper arid, arid and semi-arid (dryland) environments. Human-made artificial water sources, i.e. waste-water treatment ponds, catchments and reservoirs, have become equally important for wildlife in those areas. Bodies of open water are used by bats either for drinking and/or as sites over which to forage for aquatic emergent insects. Due to the scarcity of available water for replenishing water losses during roosting and flight, open bodies of water of many shapes and sizes may well be a key resource influencing the survival,
\end{abstract}

\section{Korine $(\bowtie)$}

Mitrani Department of Desert Ecology, Jacob Blaustein Institute for Desert Research, BenGurion University of the Negev, Sede Boqer Campus, Midreshet Ben-Gurion,

84990 Beersheba, Israel

e-mail: ckorine@bgu.ac.il

R. Adams

School of Biological Sciences, University of Northern Colorado, Greeley, CO 80639, USA e-mail: battings@yahoo.com

D. Russo

Wildlife Research Unit, Laboratorio di Ecologia Applicata, Dipartimento di Agraria, Università degli Studi di Napoli Federico II, Via Università, 100, 80055 Portici, Napoli, Italy e-mail: danrusso@unina.it

\section{Fisher-Phelps}

Department of Biological Sciences, Texas Tech University, Lubbock, TX 79409, USA

e-mail: m.fisher-phelps@ttu.edu

D. Jacobs

Department of Biological Sciences, University of Cape Town, 7701 Rondebosch,

Republic of South Africa

e-mail: David.Jacobs@uct.ac.za 
activity, resource use and the distribution of insectivorous bats. In this chapter, we review the current knowledge of bats living in semi- and arid regions around the world and discuss the factors that influence their richness, behaviour and activity around bodies of water. We further present how increased anthropogenic changes in hydrology and water availability may influence the distribution of species of bats in desert environments and offer directions for future research on basic and applied aspects on bats and the water they use in these environments.

\subsection{General Introduction}

Dryland environments which include hyper-arid, arid and semi-arid regions can be highly complex and diverse, despite being occasionally perceived as simple ecosystems supporting low species diversity (Ayal et al. 2005). Aridity is described by ratio of precipitation to potential evapotranspiration ratio (P/ETP) (UNESCO 1979, Fig. 8.1) and dryland environments are ecosystems in which typically food availability is low, precipitation is limited and unpredictable, ambient temperature is high, humidity is low, and drinking water is scarce (Noy-Meir 1973). Consequently, there are large variations in primary production by plants that can strongly affect overall species diversity and interactions (Evenari et al. 1971). Furthermore, the distribution, abundance and persistence of several desert-dwelling mammal species is affected by water availability, especially during dry summer months, when the challenges of minimizing energy use and water losses is greatest (Calder 1984; Morton et al. 1995; Lovegrove 2000; Marom et al. 2006).

In desert environments, bats are an important component of the mammalian fauna. Carpenter (1969) asserted that, based on the number of species and abundance, bats are one of the most successful desert mammals, although they are outnumbered by rodents in the driest parts of the Sahara and the Namib Desert (Findley 1993). In the deserts of Israel, insectivorous bats are the most diverse

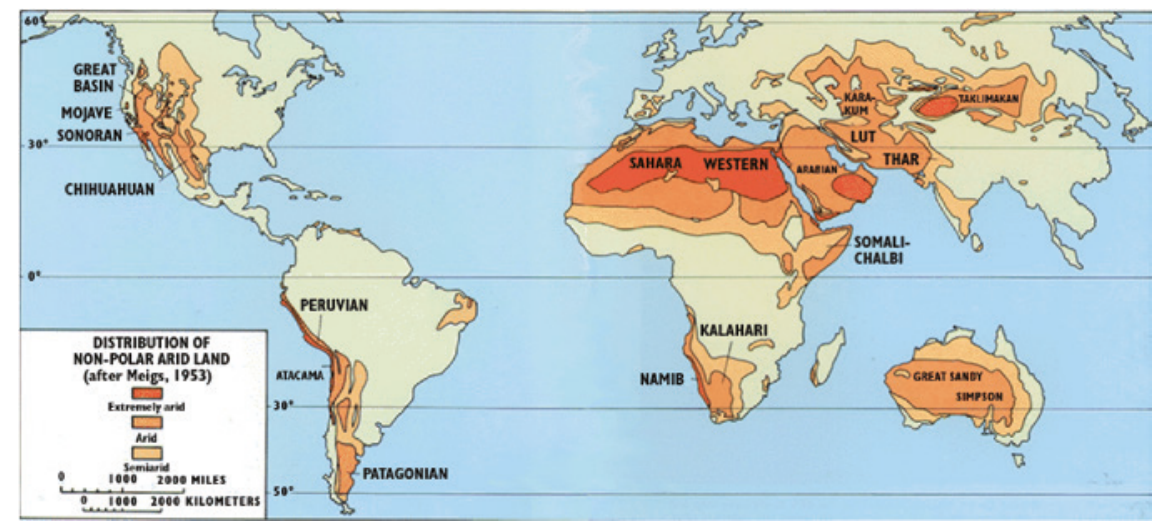

Fig. 8.1 The arid lands of the world (U.S. Geological Survey, science information services) 


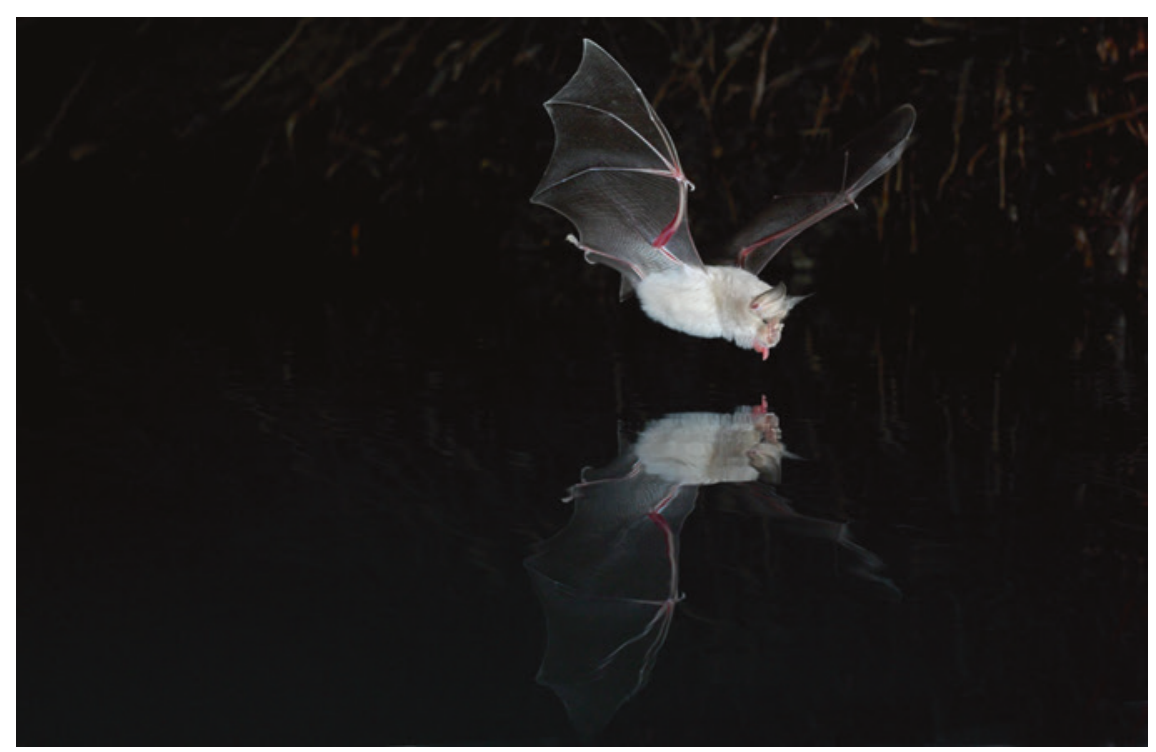

Fig. 8.2 A drinking event of the lesser horseshoe bat (Rhinolophus hipposideros) from a spring in the Dead Sea, Israel. Photo by Jens Rydell

group of mammals (Mendelssohn and Yom-Tov 1999), with 12 species recorded in the Negev Desert (Korine and Pinshow 2004) and 17 species in the Dead Sea area (Yom-Tov 1993). Benda et al. (2008) recorded 14 species of insectivorous bats in Sinai, highlighting the diversity of these mammals in desert environments. The dryland regions of South America are the most species-rich habitats of the region and have the highest number of endemic species, even when compared to the tropical lowland Amazon forest (Mares 1992; Ojeda and Tabeni 2009; Sandoval and Barquez 2013). In the Yungas dry forest of Argentina, $55 \%$ of the bat species may be endemics (Sandoval et al. 2010). However, this area is severely under-protected and very little research has been conducted on the bat fauna (Mares 1992; Sandoval and Barquez 2013) In Mongolia, more than half of the bat species only occur in arid and semi-arid regions (Nyambayar et al. 2010).

Most bats, and in particular desert-dwelling bats, use open water sources for drinking water and/or as a foraging site (Vaughan et al. 1996; Grindal et al. 1999; Ciechanowski 2002; Campbell 2009, Fig. 8.2) with various studies reporting high levels of bat activity over open bodies of water (Rydell et al. 1994; Walsh et al. 1995; Young and Ford 2000; Mickeviciene and Mickevicius 2001; Ciechanowski 2002; Russo and Jones 2003; Korine and Pinshow 2004; Williams and Dickman 2004; Anderson et al. 2006; Davie et al. 2012; Monamy et al. 2013), making even small springs, ephemeral pools and waterholes key foraging areas for insectivorous bats worldwide (Racey 1998). Water availability was even proposed as a mechanism for elevational patterns of species richness of bats in arid mountains (McCain 2007).

In this chapter, we review our current knowledge of bats and water across regionally different semi-arid and dryland environments, and the factors that may 
influence their richness, behavior and activity around bodies of water. We discuss how anthropogenic development may influence water availability and thus the distribution of species of bats in desert environments. Dryland environments are also predicted to be particularly sensitive to climate change, and we will discuss patterns by which climate disruption may further reduce water availability in arid regions. Finally, we offer directions for future research on basic and applied aspects on bats and the water they use in these environments.

\subsection{Ecology of Bats and Water in Drylands Environments}

\subsubsection{Water Sources Used by Bats}

Permanent and ephemeral pools are the central characteristic of many watersheds in dry, arid and semi-arid regions. Temporary pools have largely been ignored in management programs due to their relatively small size and apparent lack of benefit for human use (Schwartz and Jenkins 2000). However, during spring and early summer, temporary pools may serve as important foraging grounds for aquatic and terrestrial species, some of which are regionally or locally rare and/or endemic (Nicolet et al. 2004). Temporary pools in the Negev Desert had equivalent levels of species richness of bats and activity to permanent pools (Razgour et al. 2010) and the activity of bats was reduced significantly when bodies of open water were dried (Korine and Pinshow 2004), highlighting the importance of pools of all shapes and sizes to desert wildlife. In the arid regions of Mongolia, even suboptimal water sources such as small human-dug wells and salty lakes are used by bats and are an important resource for their continued survival (Nyambayar et al. 2010). Conservation efforts should therefore focus on those sources offering only temporary water availability because although they support similar bat species richness and activity levels as permanent pools, they are less likely to be protected due to their ephemeral nature.

That said, the importance of permanent pools can be underestimated if landscape availability of water is not considered through time. Geluso and Geluso (2012) analyzed 34 years of data in relation to capture rates gathered at a single drinking site, which was sampled once yearly, in the San Mateo Mountains of New Mexico. They found that in non-drought years capture success was significantly lower because bats were more dispersed across the landscape. However, in drought years, capture rates at the only available water source skyrocketed, thereby indicating the importance of open-water to local species of bats.

Data gathered on foraging patterns of bats in Utah indicated a strong affinity by Myotis bats for riparian and edge habitats as compared to other surrounding areas (Rogers et al. 2006). Similarly, Grindal et al. (1999) showed that bat activity levels were significantly greater in riparian versus upland areas in British Columbia and capture rates were higher for females than for males indicating that female bats may be more dependent on water-driven attributes of a particular area. Williams 
et al. (2006) sampled across $22.5 \mathrm{~km}$ of the Muddy River floodplain in the Mojave Desert in Nevada, which was highly disturbed by long-standing flood control, livestock grazing, and the invasion of non-native plant species, and found that the riparian woodland habitat, which represents less than $1 \%$ of the area, accounted for greater than $50 \%$ of all bat activity. Areas of historically less disturbed mesquite bosque habitat maintained higher bat activity than more disturbed areas. Fortunately, restoration of habitats can increase local species richness. In Arizona, red bats (Lasiurus blossevillii), which had not been reported before, were captured along riparian-restoration areas of the lower Colorado River. The Arizona myotis (Myotis occultus), presumed extirpated, was also captured after restoration (Calvert 2012).

In Africa, there is evidence that bat activity is higher around bodies of water than in adjacent areas. For example, in two regions in southern Africa, bat abundance was higher in riverine habitat than in adjacent, dryer savannah (Rautenbach et al. 1996; Monadjem and Reside 2008). Differences in species richness and diversity between riverine and savannah habitats were not the same in the two regions. In the Kruger National Park, there was no difference in bat species richness or evenness between riverine habitat and savannah (Rautenbach et al. 1996). In contrast, at another site in Swaziland, the riverine habitat had higher species richness and diversity (Monadjem and Reside 2008). In both regions, the two assemblages differed in the relative densities of the various species, with the savannah assemblages forming a subset of the riverine assemblages (Rautenbach et al. 1996; Monadjem and Reside 2008). This reinforces the notion that bat assemblages in less mesic regions are extensions of bat assemblages in more mesic regions, but that not all species are inclined to make use of less mesic habitats when conditions are favorable. Some of them, particularly fruit eating bats (e.g. Epomophorus crypturus; Thomas and Fenton 1978) may be restricted to riverine habitats (Monadjem and Reside 2008).

Australian studies also indicate high levels of bat activity around bodies of water (Lumsden and Bennett 1995; Williams and Dickman 2004; Griffiths et al. 2014a). Young and Ford (2000) found that species richness of bats, abundance, and capture success in the semi-arid Idalia National Park was greatest in areas adjacent to water, with $97 \%$ of captures occurring at sites with water. Bats in Uluru National Park and the north-eastern edge of the Simpson Desert predominantly use oasis habitats that have permanent or temporary water sources even in years with higher than average annual rainfall (Coles 1993; Williams and Dickman 2004). Multiple species of Australian insectivorous bats have even been recorded flying, foraging, and perhaps drinking over hypersaline environments (Laegdsgaard et al. 2004; Gonsalves et al. 2012; Griffiths et al. 2014a, b). Pteropus species in New Guinea have been recorded drinking seawater (Iudica and Bonaccorso 2003) but the prevalence of bats drinking hypersaline water in arid environments is not understood, despite natural hypersaline water bodies being common in arid and semi-arid areas in Western Australia (Halse et al. 2003; Timms 2005). In the arid regions of Mongolia, bats are mostly frequently found in association with water (Dolch et al. 2007; Davie et al. 2012). 


\subsubsection{Bodies of Water as a Drinking Source}

Water sources that are used by bats are likely to be pools in streams, lakes, ponds, slow-flowing streams and rivers and artificial bodies of water with similar properties such as farm and urban dams (Jackrel and Matlack 2010; Sirami et al. 2013), canals (e.g. Lisón and Calvo 2011), cattle troughs, swimming pools and settling ponds at waste water treatment facilities (Vaughan et al. 1996; Abbott et al. 2009; Naidoo et al. 2013, 2014) and mines having natural seepage (Donato et al. 2007; Griffiths et al. 2014a).

Both the size and accessibility of the water source influence whether a bat can drink from it. Bats drink water by swooping over a water source while lapping at the surface (Harvey et al. 1999). Because bats drink on the wing, small and more maneuverable bats are able to drink from smaller pools, whereas less maneuverable bats need a large surface area of water to skim (Tuttle et al. 2006). In the Negev Desert, Razgour et al. (2010) found that both within and between pools, species richness of bats and activity significantly increased with pond size. Furthermore, manipulations that decreased pond size led to a significant reduction in species richness and activity and affected the bat assemblage composition. The size and situation of artificial water sources similarly affect their use by bats. In the arid Texas Panhandle, USA, bats preferentially drank water from larger livestock tanks that were full and had only light vegetation around. They tended to avoid smaller, half-full tanks with denser vegetation around them (Jackrel and Matlack 2010). Although there are many anecdotal observations (Nickerson and O'Keefe 2013) of bats drinking from swimming pools there have been no formal studies of this.

Despite the central nature of drinking and water availability for bats, there are a surprisingly small number of studies addressing this topic in Europe, even though many species do drink at open water sources regularly to rehydrate (e.g. Russo et al. 2012). Some appear more sensitive than others to water deprivation because of their stricter dependence on water habitats. For instance, in water-denial experiments Daubenton's bat, Myotis daubentonii, a species selectively dwelling in riparian habitat and above bodies of open water, has been found to undergo a greater body mass loss and to show signs of dehydration earlier than the brown long-eared bat, Plecotus auritus, a forest bat (Webb et al. 1995). Drinking sites are also of chief importance for European bats outside the semiarid Mediterranean region. In the Bavarian Forest, Germany, oligotrophic, acidic ponds are used by over a dozen species of bats for drinking (Seibold et al. 2013). Likewise, in the Italian Apennines, water cattle troughs built for traditional livestock breeding are frequently used to drink by over a dozen species of bats. Such small (often less than $15 \times 1.5 \mathrm{~m}$ ) pools of water are locally of extreme importance (Russo et al. 2010, 2012) for several threatened species (Fig. 8.3). These pools also concentrate insects, so bats occasionally forage there, but their importance for drinking is overwhelming (Russo et al. 2012). The disappearance of traditional livestock breeding due to rural depopulation in many Apennine areas has led to the abandonment of the cattle troughs, implying an unstudied yet potentially high cost for bat 

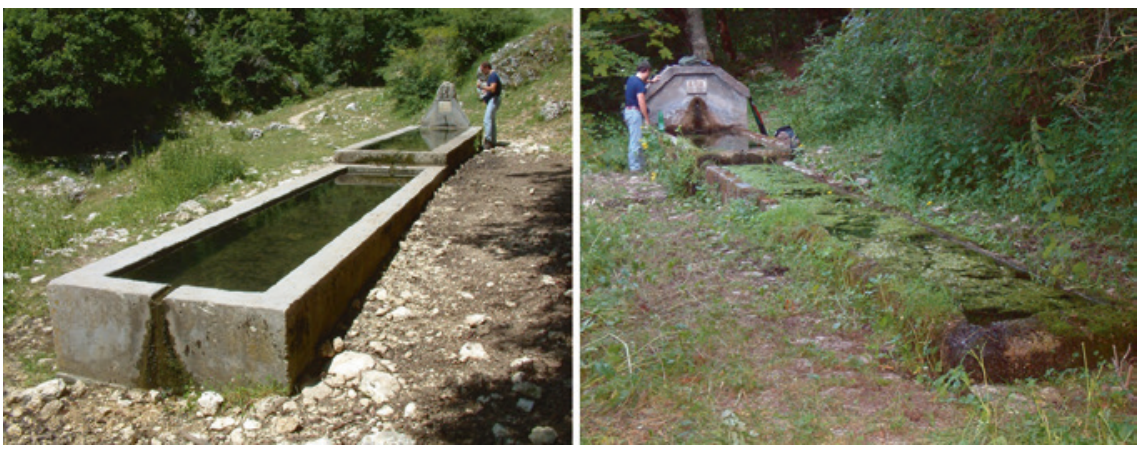

Fig. 8.3 Cattle troughs used by drinking bats in the Italian Apennines. Photo by Luca Cistrone

populations (Fig. 8.3). In Italian forests, bats also drink from the small ephemeral pools which form following heavy rain and only last few days or weeks (D. Russo, pers. obs.). Eavesdropping on other drinking bats is likely to play an important role in locating such sites and this behaviour is typical of species with manoeuvrable flight such as the barbastelle bat, Barbastella barbastellus, and the greater horseshoe bat Rhinolophus ferrumequinum.

\subsubsection{Bodies of Water as a Foraging Habitat}

The tendency for higher insect abundance near water sources attracts bats to use water sources as foraging habitats. Furthermore, calm surface water provides a less cluttered acoustic signal return from the echolocation pulses (Mackey and Barclay 1989; Siemers et al. 2001), and there is some evidence, at least for echolocating bats, that activity over calm pools of water is higher than that over fastflowing riffles (von Frenckell and Barclay 1987). Bat activity in a transect from dry woodland savannah to riverine habitat in southern Africa was correlated with insect abundance-both bat activity and insect abundance were higher in riverine habitat (Rautenbach et al. 1996) suggesting that bats were attracted to this habitat because of the feeding opportunities it provided.

Drought is known to reduce the abundance of insects in temperate zones (Frampton et al. 2000) and thus affect reproduction in insectivorous bats (Rhodes 2007). An eight year study by Bogan and Lytle (2011) on aquatic insects living in two study pools of a formerly perennial desert stream in the Whetstone Mountains of Arizona, USA, showed that complete water loss followed by intermittent flow caused a catastrophic regime shift in community structure that did not recover to the pre-drying configuration even after four years. Ledger et al. (2011) found significant reduction in and suppression of secondary productivity by drought that could have severe constraining effects on terrestrial vertebrate predator populations, and Love et al. (2008) found similar effects in Arkansas, USA. Furthermore, 
desert bats in Arizona responded to artificial-light-induced food patches (Fenton and Morris 1975) and one would presume this would be similar when small pools of water create swarms of high insect density. All of these data together suggest that small water sources with intermittent flow are vitally important as foraging sites to at least some insectivorous desert bat species.

In Europe, three species of bats are aquatic habitat specialists: Daubenton's bat, M. daubentonii, the long-fingered bat, Myotis capaccinii, and the pond bat, Myotis dasycneme. Besides taking insects in flight by aerial hawking, they typically forage very close to the water surface, from which prey is gaffed with their large feet or the inter-femoral membrane and transferred to the mouth while on the wing (Kalko and Schnitzler 1989; Siemers et al. 2001). Chironomidae and Trichoptera are frequent prey items of these bats (e.g. Biscardi et al. 2007; Krüger et al. 2012). $M$. capaccinii may seize adult chironomids from the water surface as they emerge from pupal casings. Trawling bats mainly forage over calm water whose surface is free from ripples (Rydell et al. 1999) as echoes from clutter interfere with prey detection (Siemers and Schnitzler 2004). On windy nights, $M$. capaccinii and $M$. daubentonii are less active (Russo and Jones 2003), presumably because wind reduces prey density and generates ripples on the water surface affecting target detection. In such circumstances, bats forage at sheltered sites where water is calmer (Lewis and Stephenson 1966; Lewis 1969).

Several other species of bats frequent riparian habitats to forage and/or drink, especially the soprano pipistrelle, Pipistrellus pygmaeus (e.g. Nicholls and Racey 2006), Nathusius' pipistrelle, Pipistrellus nathusii (Flaquer et al. 2009), and other Pipistrellus spp. (Scott et al. 2010), Schreiber's bat Miniopterus schreibersii (Serra-Cobo et al. 2000) and noctules, Nyctalus spp. (Rachwald 1992; Racey 1998; Vaughan et al. 1997). The stricter reliance on riparian habitats is one of the main ecological factors distinguishing P. pygmaeus from its sibling P. pipistrellus (but see Warren et al. 2000) and allowing interspecific niche partitioning and thus coexistence (Oakeley and Jones 1998; Nicholls and Racey 2006; DavidsonWatts et al. 2006; Sattler et al. 2007). However, local factors such as elevation or landscape composition may influence differences across species. At larger scales, the presence of main rivers and wetland areas are important as migratory paths and offer important stopover sites to migrating bats across Europe (Flaquer et al. 2009). Rivers and riparian vegetation also constitute important linear landscape elements used for navigation by several European bats (Serra-Cobo et al. 2000; Russo et al. 2002).

As might be expected given the above, the quality of foraging areas lacking water is influenced by their distance to water. In Portugal, proximity to a drinking water source increased foraging habitat quality for Mehely's horseshoe bat Rhinolophus mehelyi and M. schreibersii (Rainho and Palmeirim 2011). Similarly, a radio-tracking study of $R$. mehelyi in Spain showed that although this species hunted predominately in forest, the foraging areas were always within $500 \mathrm{~m}$ of a water source (Salsamendi et al. 2012), possibly to allow for easy rehydration between foraging bouts or perhaps to take advantage of water-emergent forest insects. In historic landscape parks of England (Glendell and Vaughan 2002) as 
well as in German forests (Kusch and Idelberger 2005) the relative area of available water surface is an effective proxy for levels of bat activity.

Australian bats have also been documented preferentially foraging around water sources. When compared to other habitat types in the Simpson Desert, more feedings buzzes were recorded around permanent and temporary water sources (Williams and Dickman 2004). Bats will also forage over hypersaline water bodies but more feeding buzzes are recorded over freshwater sites (Griffiths et al. 2014b). There is also evidence (e.g. Aldridge and Rautenbach 1987; Schoeman and Jacobs 2003, 2011; Naidoo et al. 2011, 2013) that insects associated with freshwater habitats (e.g. Plecoptera, Ephemeroptera and Trichoptera) occur in the diet of southern African bats.

\subsubsection{Water, Roosts and Reproduction}

The propensity for female bats to choose roost sites that are relatively high in ambient temperature is thought to help them save metabolic energy by allowing for continued gestation of the young during torpor (Speakman et al. 1991; Adams and Thibault 2006; Daniel et al. 2010). The cost of such a choice in roost sites in arid regions, however, is the propensity for high-levels of evaporative water loss during the diurnal roosting cycle (Webb 1995) and this is further exacerbated when females are lactating (Kurta et al. 1990). The only quantitative field study to assess the need for drinking water by lactating female bats in drylands used PIT-tagged lactating and non-reproductive females from a maternity colony of fringed myotis (Myotis thysanodes) in Colorado, USA. Adams and Hayes (2008) found that lactating females visited to drink an average of seven times more per night than did non-breeding adult females. In addition, lactating females visited to drink consistently night after night regardless of daily relative humidity and temperatures, whereas non-reproductive females visited more when temperatures were high and relative humidity low (Adams and Hayes 2008).

In addition, Adams (2010) synthesized 13 years of capture data from the same field sites in Colorado, USA and found that summer mean precipitation had the highest correlation with reproductive frequency followed closely by mean stream discharge rates. Of these two, the latter showed the most abrupt effect on bat reproduction. When stream discharge rates were lower than $7 \mathrm{~m} / \mathrm{s}$, the frequency of reproductively active females captured plummeted, in some years by as much as $50 \%$. When female reproductive condition was plotted against mean stream discharge, the frequency of lactating females tracked the amount of available water, whereas the frequency of pregnant females was not correlated. This suggests that during drought years pregnant females may give birth, but do not have access to enough drinking water to support lactation. O'Shea et al. (2010) using mark/recapture of big brown bats, Eptesicus fuscus, at maternity colonies in Ft. Collins, Colorado, USA found that first year survival was lowest in bats born during a drought year, although other factors were also at play. 
Several species of bats have been found to roost close to bodies of water to minimize the energy expenditure required to reach important drinking or foraging sites (Racey 1998; Korine et al. 2013). The need to drink directly after emerging from the roosts may be the main factor determining the proximity of roosts to water, especially for maternity colonies (Racey 1998). M. daubentonii, whose foraging strictly depends on water habitat, often uses bridges over rivers, as well as buildings or cavity-bearing trees in the immediate surroundings of riparian biotopes (Racey 1998; Parsons and Jones 2003; Lučan and Radil 2010; Encarnação 2012). Several other species, such as Natterer's bat (Myotis nattereri), pipistrelles (Pipistrellus spp.) and brown long-eared bat, also tend to roost in landscapes comprising bodies of water that provide drinking and foraging opportunities (Racey 1998; Entwistle et al. 1997; Oakeley and Jones 1998). Floodplain forests of central Europe host important reproductive colonies of tree-roosting noctule bat Nyctalus noctula (Görföl et al. 2009). Myotis macropus, an Australian species, has a variable roosting behaviour but the primary force behind roost selection is proximity to waterways (Campbell 2009).

\subsection{Threats to Water Sources Used by Bats}

In drylands, where water resources are scarce, any loss of or degradation to open water source, such as a reduction in water quality, may create cascading affects that will be harmful to the wildlife that depends on it. When bats drink from a polluted source they ingest toxins directly and during foraging they indirectly ingest toxins that may have bio-accumulated within their insect prey. For example, if insect larvae feed on microorganisms in polluted water, they concentrate the pollutants in their bodies and when they metamorphose into adults these are consumed by bats. The effect of environmental chemical containments on bats was reviewed in 2001; most studies have occurred in Europe ( $50 \%)$ and North America $(\sim 34 \%)$ mostly pertaining to organochlorine insecticides (58\%), metals (30\%), and polychlorinated biphenyls or PCBs (13\%) (Clark and Shore 2001). There are hardly any reports on the effect of polluted water on bat activity and richness in the drylands of North Africa, the Middle East and South America. Levels of bat activity in the Negev Desert were very high over wastewater treatment ponds (Korine and Pinshow 2004), however species richness was low and the majority of the activity was attributed to Kuhl's pipistrelle (Pipistrellus kuhlii). Pilosof et al. (2013) showed that sewage pollution in the Negev desert affected the immune response of Kuhl's pipistrelle and Naidoo et al. (2014) reported on DNA damage to bats that forage at wastewater treatments work. 


\subsubsection{Loss of Sources of Water}

An estimated two-thirds of Earth's freshwater flowing to oceans is obstructed by anthropogenic development (Nilsson and Berggren 2000), with approximately 75,000 dams in the USA alone and the majority of natural wetlands having been destroyed as well. Although not the scope of this chapter, it is important to mention that for bats, wetlands provide critical foraging habitat (Johnson et al. 2008; Rainey et al. 2006) with absolute area and connectivity of wetlands being important components for foraging (Lookingbill et al. 2010).

Indeed, a recent report on total wetland loss in the USA from 2004-2009, showed a $25 \%$ reduction from the previous reporting period. In addition, a total of 95,000 acres of saltwater wetlands and 265,720 acres of freshwater wetlands were lost (Dahl and Stedman 2013). The situation is exacerbated in the western USA, where livestock grazing has damaged at least $80 \%$ of stream and riparian ecosystems (Belsky and Matzke 1999). The consequences for bats are illustrated by observed declines in bat activity as related to flow-reduction and drying along the San Pedro River in Arizona. Moreover, these declines corresponded to declines in insect availability at perennial sites and both bat activity and insect activity declined to imperceptible levels in areas where the river dried up (Hagen and Sabo 2012).

European rivers, lakes and wetlands are among the most seriously altered ecosystems. Human impact has caused a major structural or chemical degradation of such ecosystems with fatal repercussions for their associated biota (e.g. Abel 1996). Alteration of European rivers has often led to the loss of channel features, floodplain connectivity and structure of bank vegetation. A threatened vespertilionid, $M$. capaccinii, selects foraging sites where water is less polluted and riparian vegetation better preserved. Along with the loss or disturbance of suitable cave roosts (Papadatou et al. 2008), riparian habitat alteration poses the main threat to this bat (Biscardi et al. 2007).

Australian rivers have the highest variation in flow and flooding in the world (Williams 1981; Puckridge et al. 1988). Anthropogenic activities such as extraction and diversion of water have had adverse impacts on rivers in the arid-zone of Australia (Walker 1985; Kingsford and Thomas 1995). High natural variation in water availability coupled with anthropogenic activities and climate change has the potential to catastrophically affect arid-species that depend on water availability (Roshier et al. 2001; McKenzie et al. 2007; Saunders et al. 2013).

A major concern associated with natural rivers and lakes in urban areas is that they may be polluted by runoff from roads or other sources. When bats drink from these sources, they ingest these pollutants directly or indirectly by feeding on aquatic-emergent insects. Sources of pollution of farm and golf course dams include feces from livestock and wild animal, nitrate and phosphate in fertilizers, metals, pathogens, sediments and pesticides. Unfortunately, little research has been done on the use of polluted urban water sources by bats and the probable health impacts on bats. The little evidence that does exist suggests that at least 
some species of bats may not avoid polluted bodies of water in arid areas (Pilosof et al. 2013; Korine et al. 2015). In Durban, South Africa bat abundance and species richness were higher over a polluted than over an unpolluted river and bat feeding activity (measured by feeding buzzes in the echolocation sequences) was also higher at the polluted river. There was, however, no difference in insect diversity between the two rivers (Naidoo et al. 2011) and, with the exception of a single species, Rufous mouse-eared bat, Myotis bocagii, proportions of prey items in the diets of bats did not correspond to their proportion in the insect fauna. M. bocagii fed predominantly on Diptera and this was also the most abundant insect in the insect light traps (Naidoo et al. 2011).

\subsubsection{Mining}

Mining is a major anthropogenic source of environmental destruction and contamination globally. Toxins associated with extensive mining operations, in particular, gold mining is well documented. Cyanide used to extract gold from ore is commonly stored in open ponds, some of which are 200 acres in size. The actual numbers of bats, and other wildlife killed by drinking at these ponds is poorly understood and very difficult to track as many affected individuals either become submerged, or die from drinking contaminated water after leaving the site. Between 1980 and 1989, 34 \% of all known mammals killed at cyanide ponds used for mining gold in California, Nevada, and Arizona were bats (Clark and Hothem 1991).

Other heavy metals used in mining operations such as arsenic, cadmium, chromium, copper, lead, mercury, methyl mercury, nickel, and zinc have been found in bat carcasses. In Arizona, USA where at least $20 \%$ of bat populations are in decline (King et al. 2001), Mexican free-tailed bats (Tadarida brasiliensis) living $8 \mathrm{~km}$ from a major copper smelting mine had accumulated significant levels of atmospheric mercury in their tissues (Petit 2007). In another study in Arizona, pallid bats (Antrozous pallidus), western pipistrelles (Parastrellus hesperus), and $T$. brasiliensis had elevated mercury levels in their liver and muscles that they most likely acquired via drinking from contaminated free-water sources (Reidinger 1972; see also Syaripuddin et al. 2014).

Besides contaminated ponds, natural water flows through thousands of abandoned mines in the western USA (used by bats for hibernaculum and maternity roosts) may be highly contaminated with heavy metals. For example, at Sheep Tank Mine overlooking the Colorado River in Arizona, barium, manganese and zinc were detected in soil samples at concentrations 10 times normal levels and $E$. fuscus captured at the site had higher concentrations of these elements than those collected from three other sites (King et al. 2001). Other species included in the study had high arsenic levels as well as other contaminants (copper, lead, barium, manganese, and zinc) (King et al. 2001). Bats and other terrestrial vertebrates can also be exposed to high levels of contaminants by ingesting aquatic emergent 
insects living in toxic streams and High levels of bioaccumulated cadmium and zinc are known to occur as far as $381 \mathrm{~km}$ downstream from the pollution source, whereas lead was found to be transferred from sediments to chironomids (midges) only as far as $40 \mathrm{~km}$ downstream (Cain et al. 1992). Thus, large stretches of streams and rivers far from the point source of contamination pose threats to bats and other aquatic and terrestrial wildlife.

Bats are also known to fly and possibly forage/drink over gold mines in Australia (Donato and Smith 2007; Smith et al. 2008). High bat activity was recorded over gold mine water bodies containing cyanide (Griffiths et al. 2014a). Griffiths et al. (2014b) suggested that elevated salt levels in water bodies at gold mines may decrease bat activity, foraging, and drinking. Bats, including the Vulnerable (IUCN 2014) ghost bat, Macroderma gigas, have also been recorded around an Australian copper mine in the Great Sandy Desert, although the mine's effects on individuals or the population is unknown (Read 1998).

Africa is rich in mineral resources and this makes mining activities relatively common so likely a serious threat to water quality and therefore to bats. A matter of grave concern is that no research has been done in Africa in this regard. This situation prevails despite evidence that mining activities do pollute surface water in Africa (Olade 1987; Naicker et al. 2003).

\subsubsection{Agriculture}

Organochlorine pollution of streams and rivers, and other sources, is of major concern for bats (see Bayat et al. 2014 for review). Experimental testing of organochlorine insecticides such as DDT on two species widely distributed throughout the USA, found that Myotis lucifugus was approximately twice more sensitive than were E. fuscus. Furthermore, juvenile E. fuscus were 1.5 times more sensitive than adults (Clark et al. 1978). In addition, tests showed that individuals of T. brasiliensis poisoned with DDT survived for some time but later died of DDT poisoning mobilized from fat during active flight after being starved (Clark et al. 1975). Laboratory studies also show that presence of organochlorine in tissues can accelerate the catabolism of fat, causing DDE-dosed bats (M. lucifugus) to lose weight faster than control bats (Clark and Stafford 1981). Although banned in the USA in 1972, significant levels of DDT and DDE have been documented in tissues collected from bats foraging and drinking at the Rocky Mountain Arsenal Superfund Site (O'Shea et al. 2001). High DDT concentrations are also found in M. lucifugus tissues in the Eastern United States (Kannan et al. 2010). Furthermore, post-ban persistence of DDT in USA bats has been verified by sampling guano at roost sites (Clark et al. 1982; Reidinger and Cockrum 1978; Bennett and Thies 2007). DDT has also been found in bat tissues in Australia despite being banned since 1987 (Mispagel et al. 2004; Allinson et al. 2006). DDT for agricultural use was essential banned worldwide in 2001, but recent work from Africa showed that DDT is probably still being used and accumulating in the tissues of multiple species of bats (Stechert et al. 2014). 
The two most common agricultural pollutants are nitrogen and phosphorus and sources of these pollutants include inorganic and organic fertilizers, leguminous crops, septic tanks, farm and municipal waste water treatment facilities, and, in the case of phosphorous, run-off from groundwater discharge and atmospheric deposition. An excess of these nutrients is the leading cause of aquatic eutrophication (Shabalala et al. 2013). Inorganic pollutants such as metals from agricultural and industrial run-off can also accumulate in these sites as well as in the tissues of insects using these bodies of water. Bats feedings on such insects are thus at risk of ingesting high levels of toxic metals such cadmium, chromium and nickel (see Naidoo et al. 2013).

\subsubsection{Waste Water}

European bats foraging in aquatic habitats are known to be largely exposed to toxic heavy metals which bioaccumulate in their insect food (Pikula et al. 2010). Organic pollution of rivers is also known to affect bat foraging, but its effects are variable. A British study compared the differences in bat activity found respectively upstream and downstream from sewage outputs and showed that downstream activity of pipistrelle bats decreased whereas that of $M$. daubentonii increased relative to upstream sites (Vaughan et al. 1996). The latter species is thought to benefit from the higher downstream abundance of pollution-tolerant prey such as chironomids. However, an Irish study obtained opposite results, with $P$. pygmaeus being more common downstream of sewage effluent discharges than M. daubentonii (Abbott et al. 2009). Park and Cristinacce (2006) compared the effects of two types of sewage treatment works for foraging bats: those with percolating filter beds, often hosting many insects potentially important for bats, and the "activated sludge" system - gradually replacing the former-in which sewage and bacteria-laden sludge are mixed and agitated so that they prove inhospitable for the invertebrate fauna. The study showed that both insect biomass and bat activity were higher at percolating filter beds and that bat activity there was comparable to that recorded at nearby natural foraging habitats. However, bats may run serious risks when foraging at such sewage treatment works: endocrine disrupting chemicals, which may alter the endocrine functions in exposed animals, have been found to concentrate in bat insect prey at percolating filter beds, with potentially harmful effects on foraging bats (Park et al. 2009).

There has been very little research in Africa on the concentration of pollutants in tissues of bats and no work on the long and short term effects of these pollutants on the health of bats. There is some evidence of the presence of the toxic metals cadmium, chromium and nickel in tissues of African bats foraging at sites downstream of waste water treatment plants (Naidoo et al. 2013). Furthermore, bats foraging over waste water treatment facilities display increased haematocrit and DNA damage and decreased antioxidant capacity in muscle tissue compared to bats that forage over unpolluted sites. Although these effects were not lethal they may result 
in long-term negative effects on the health of bats (Naidoo et al. 2014). These metals were probably ingested by bats via their insect prey.

There is evidence that aerial insects developing in sewage sludge and waste water at sewage treatment plants can accumulate pollutants that could disrupt endocrine functioning (Park et al. 2009). However, a similar study on the activity of the insectivorous bat, the banana bat, Neoromicia nana, at three urban rivers systems above and downstream of where sewage effluent enters these rivers revealed that the relative abundance and feeding activity of $N$. nana were higher at polluted sites downstream of where sewage entered the system than at the unpolluted sites upstream (Naidoo et al. 2013). In this case the bats may have been attracted by the higher abundance of dipterans over the polluted sites. Diptera were the dominant prey items in both the insect fauna at the polluted sites and in the diets of the bats (Naidoo et al. 2013). This also appeared to be the case for M. bocagii which also fed predominantly and opportunistically on Diptera (Naidoo et al. 2011).

The response by bats to rivers affected by waste water treatment effluent may vary both between and within species. In North America (Kalcounis-Rueppell et al. 2007) and England (Vaughan et al. 1996), some species were more active upstream from where waste water effluent entered the rivers while others were more active downstream. It appears that these differences arise from the differential effects of euthrophication on insect prey as well as on the responses of bats. Some species take advantage of eutrophication that causes an increase in the abundance of their preferred prey, and other species which apparently do not feed on insects that are affected by eutrophication, prefer to forage in less polluted habitats. Furthermore, these differences may also result from differences in the foraging behavior of the same species at different sites. For example, N. nana fed opportunistically on the small abundant dipterans at wastewater polluted sites, but at unpolluted river sites fed selectively on insects from other orders (Naidoo et al. 2013).

Another major anthropogenic compound found in open bodies of water in the USA is polychlorinated biphenyl or PCB, a common industrial waste product that was banned by the United States in 1979 and the United Nations in 2001. PCB poisoning in pregnant $M$. lucifugus led to stillborn young (Clark and Krynitsky 1978). Aquatic-emergent insects are key exporters of contaminants to terrestrial ecosystems (Menzie 1980; Runck 2007) and data show significant lateral transfers of PCBs to terrestrial riparian predators such as spiders, reptiles and amphibians (Walters et al. 2008). High concentrations of PCB's have been found in fat tissues of M. lucifugus in New York and Kentucky (Kannan et al. 2010). Along the fresh water tidal river, the Biesbosch, in the Netherlands, direct transfer from river sediments to chironomids to pond bats occurred in concentrations known to cause negative reproductive effects in mink (Reinhold et al. 1999). Frick et al. (2007) investigated the effects of an accidental chemical spill (metam sodium) on Yuma myotis (Myotis yumanensis) in California and found reduced female juvenile survival, but not adult female survival. The spill-affected population declined significantly during the first years of the study. Although the population increased in year four, this also coincided with an end to an extensive regional drought. Controlled 
experimental exposure to Lindane (an organochlorine used in wood preservatives) at sublethal levels in $P$. pipstrellus increased $24 \mathrm{~h}$ metabolic rates of a $7.3 \mathrm{~g}$ individual by $15 \%$ and in a $6.3 \mathrm{~g}$ individual by $23 \%$, thereby posing a significant threat to survivorship of free-living individuals (Swanepoel et al. 1999) and showing that sub-lethal exposure can affect energetic balance.

\subsection{Mitigation and Restoration}

Both the availability and distribution of water in drylands have been drastically altered by natural processes such as decline in annual precipitation, and by anthropogenic developments such as irrigation for agriculture, over exploitation of groundwater and human-induced climate changes.

\subsubsection{Restoration of Water Sources and Related Habitats}

Most wetlands have been altered globally due to anthropogenic disruption, pollution, and outright destruction. In some, but too few, places, humans have begun to restore some of those wetlands. For example, in the USA, the Sierra Nevada Conservancy is working in cooperation with State Parks, the Department of Toxic Substances, California State University Chico and others, to identify mercury sources and potential remediation strategies for an abandoned hydraulic mine discharging sediment and heavy metals into the Yuba River and removing mercury from dredged sediment that have accumulated in the Combie Reservoir.

In California, restoration of the Cosumnes River floodplain re-established bat activity that broadly corresponded with flooding and an increase in aquatic emergent insects (Rainey et al. 2006). Furthermore restoration of riparian habitat, frequently damaged by cattle as well as other anthropogenic uses, and wetlands commonly destroyed by human development, is essential and is occurring in some areas, but well below necessary levels for bat conservation (Goodwin et al. 1997).

Despite some of the negative effects highlighted in the previous section concerning waste water effluent, wastewater reclamation is an important process especially in areas where water is scare (Anderson et al. 2001). Wastewater can be used to construct artificial wetlands that provide habitat for wildlife if the water is properly treated (Greenway and Simpson 1996; Fujioka et al. 1999; Greenway and Woolley 1999; Greenway 2005). Some studies have found that increased nutrient loads, such as those caused by wastewater effluent may have a positive effect on insect and bat abundance both in US and European streams (Kokurewicz 1995; Vaughan et al. 1996; Abbott et al. 2009). One US study found that bat activity and foraging levels were the same up-stream and down-stream of wastewater discharge but community structure was altered, with the riparian-specialist Perimyotis subflavus being more abundant (Kalcounis-Rueppell et al. 2007). 


\subsubsection{Artificial Water Sources}

One way to overcome the diminishing of natural water sources in many drylands is the development of artificial catchments which are widely used for wildlife management (Krausman et al. 2006). There has long been controversy regarding the effects of catchments on local wildlife, in which critics argue that these developments do not yield expected benefits to game species and may have opposing impacts such as predation (O'Brien et al. 2006).

Small artificial ponds may be of utmost importance for wildlife (Russo et al. 2012). The large-scale expansion of intensive agriculture in semiarid Mediterranean climates has often been sustained by hydraulic engineering works, to cope with the scarcity of natural irrigation water. In southeastern Spain, Lisón and Calvo (2011) studied the effects on bats of a water transfer channel and a related network of irrigation ponds in a mixed landscape of traditional and intensive agricultural landscape. In general, artificial bodies of water had a positive effect on bat activity, but this mainly regarded common, generalist species (P. pipistrellus and P. pygmaeus) most likely because of the absence of foraging habitats suitable for more specialized species (those bearing a higher conservation value) such as riparian vegetation. In Catalonia, rice paddies sustain high bat activity, providing large amounts of insect prey. However, roost availability was the main limiting factor and installing bat boxes represents a valuable strategy to increase bat populations (Flaquer et al. 2006). In the arid Ikh Nart Nature Reserve in Mongolia, significantly more bats were caught at natural springs relative to human-made wells and no bats were captured at sites without water (Davie et al. 2012). This suggests that at least for this area, replacing lost natural water sources with artificial ones may not be as effective for preserving bat populations as conserving natural water sources.

Paradoxically, the creation of large water reservoirs may prove harmful to the entire bat community. Rebelo and Rainho (2009) looked at the effects on bats of the largest reservoir in Europe, created by construction in 2001 of the Alqueva dam, in Alentejo, Southern Portugal. The project led to the deforestation and submersion of an area of ca. $250 \mathrm{~km}^{2}$. Consequently, bat populations were affected by the sudden disappearance of ca. $200 \mathrm{~km}$ of riparian habitat, together with largescale roost loss and the replacement of important habitat with a vast homogeneous one which was not used by foraging bats. Noticeably, bat activity showed a strong decline in the submerged areas but increased in the surrounding unaffected habitat.

The expansion of Mediterranean species into surrounding arid wildlife communities may have a negative impact on local populations such as competition for the use of pools for drinking and foraging. Nine of the $12 \mathrm{Negev}$ species of bats (Korine and Pinshow 2004) are associated with arid areas, and the Kuhl's pipistrelle, the European free-tailed bat (Tadrida teniotis), and the rare lesser horseshoe bat (Rhinolophus hipposideros) - are Mediterranean species that have expanded their distribution into the Negev in the twentieth century (Yom-Tov and Mendelssohn 1988). The most common bat in some desert habitats and in 
particular at artificial water sites in the Negev is Kuhl's pipistrelle (Korine and Pinshow 2004). The expanded distribution is probably linked to human settlements and in particular to artificial bodies of water since non-desert species of bats must drink on a daily basis and drink more frequently compared with desert-dwelling bats (Razgour 2010). Kuhl's pipistrelle competes for the use of pools for drinking and foraging, resulting in temporal and spatial partitioning between local desert bat species (Razgour et al. 2011). The documented competition between Kuhl's pipistrelle and desert-dwelling bat species (Polak et al. 2011; Razgour et al. 2011), combined with the increasing development of bodies of open water in the Negev and other drylands, may lead to further resource competition resulting in loss to the region's biodiversity. Korine et al. (2015) have shown that species richness and activity of desert dwelling bats did not differ between artificial and natural bodies of water in the Negev desert, however several species of bats drank or foraged only at natural bodies of water.

\subsection{Conclusion and Future Directions}

Human population growth, land use change and habitat loss have led to massive habitat alterations and destruction, particularly of water sources in arid regions. The availability of water (temporary/permanent) appears to have a strong positive influence on species of bats richness and activity. This suggests that large temporary pools are important for the conservation of bats in arid environments. A reduction in the availability of temporary pools, due to intensification of arid conditions, is expected to predominantly affect species of bats that forage over water, and will most likely increase interspecific competition for foraging space above the pools. These problems are likely be exacerbated in species of bats that are able to extend into arid areas because of their association with humans. Studies on the distribution of bats in drylands on a large scale should be the focus of future research to understand how climate change and introduction of artificial bodies of water effect species distribution, activity and richness. Studies are strongly needed in arid regions to understand the best and most efficient way to provide safe artificial water sources for bats that can mitigate increased incidences of drought due to climate change and, in some cases, the total loss of available water, especially in the more temperate arid regions with shorter growing seasons. For example, placement of artificial water sources near maternity roosts is instrumental in arid temperate areas with shorter growing seasons (Adams 2010). However, the introduction of artificial bodies of water may promote invasion by non-native species and range expansion of others, leading to resource competition. In regions of Europe likely to become water-stressed because of human induced climate changes, bats may be affected as they may lack the physiological means to cope with water limitation (Sherwin et al. 2013).

Africa, as well as other arid areas such as the Negev and the Mongolian deserts, has a high diversity of bats but compared to other areas of the world its bat fauna 
has been little studied. Fundamental research is most needed throughout Africa and other arid zones on how often bats need to drink and whether this varies across species, geographically and seasonally. Comparative studies on bats with distributions restricted to arid regions and species that have populations in mesic and arid regions would be particularly informative in this regard. For example, the diversity of renal capacities and habitat use amongst African species of bats of the same family (Happold and Happold 1988), and the emergence of robust family level phylogenies (e.g. Stoffberg et al. 2010) provide an excellent opportunity to study the evolution of renal form and function in African bats in an ecological context. Special focus should be placed on research determining the extent to which African bats are reliant on artificial water sources. Such research should target arid zone species of bats, especially those species that live in close association with humans because these are the species likely to be impacted by insufficient or polluted water sources.

Research is also needed on whether all water sources are used for both drinking and foraging and how bats respond to decreases in water quality as a result of pollutants. Do certain species of bats avoid drinking from low quality bodies of water as shown by Korine et al. (2015)? Would bats still use polluted bodies of water for feeding but not for drinking? If so, how do they detect low quality water, do they do so before they are adversely affected by it and do they have alternative water sources? How are desert-dwelling bats affected by pollutants in water or by waterborne toxins and pollutants in the insect fauna, and are such bats able to deal with such pollutants physiologically?

Although least is known about bats and water in sub-Sahara Africa, studies thus far in other regions of the world are in their infancy in terms of understanding the long-term effects of decreased water availability on bat and other wild populations. Due to human destruction of wetlands and riparian habitats as well as unsustainable human population growth that more and more is utilizing greater amounts of fresh water, availability of fresh water to sustain wildlife populations are reaching critically low levels, especially in areas suffering from extended droughts due to human-induced climate disruption. Because water is a key ingredient of all life, focus on this topic needs to increase and because bats act as 'canaries in a global coal mine,' studies concerning bats and water are key to better management of water resources in natural and artificial areas.

Acknowledgments We would like to acknowledge four anonymous reviewers and Dr. Tigga Kingston for their helpful comments on the chapter. RAA thanks the University of Northern Colorado, the Department of Open Space and Boulder Mountain Parks, Boulder County Department of Parks and Open Space for providing funding for research. This is paper number 871 of the Mitrani Department of Desert Ecology.

Open Access This chapter is distributed under the terms of the Creative Commons Attribution Noncommercial License, which permits any noncommercial use, distribution, and reproduction in any medium, provided the original author(s) and source are credited. 


\section{References}

Abbott IM, Sleeman DP, Harrison S (2009) Bat activity affected by sewage effluent in Irish rivers. Biol Cons 142:2904-2914

Abel PD (1996) Water pollution biology. Taylor and Francis, London

Adams RA (2010) Bat reproduction declines when conditions mimic climate change projectionsfor western North America. Ecology 91:2437-2445

Adams RA, Hayes MA (2008) Water availability and successful lactation by bats as related to climate change in western regions of North America. J Anim Ecol 77:1115-1121

Adams RA, Thibault KM (2006) Temporal partitioning by bats at water holes. J Zool 270:466-472

Aldridge HDJN, Rautenbach IL (1987) Morphology, echolocation and resource partitioning in insectivorous bats. J Anim Ecol 56:763-778

Allinson G, Mispagel C, Kajiwara N, Anan Y, Hashimoto J, Laurenson L, Allinson M, Tanabe $S$ (2006) Organochlorine and trace metal residues in adult southern bent-wing bat (Miniopterus schreibersii bassanii) in southeastern Australia. Chemosphere 64:1464-1471

Anderson J, Adin A, Crook J, Davis C, Hultquist R, Jimenez-Cisneros B, Kennedy W, Sheikh B, van der Merwe B (2001) Climbing the ladder: a step by step approach to international guidelines for water recycling. Water Sci Technol 43:1-8

Anderson J, Law B, Tidemann C (2006) Stream use by the large-footed myotis Myotis macropus in relation to environmental variables in northern New South Wales. Aust Mammal 28:15-26

Ayal Y, Polis GA, Lubin Y, Goldberg DE (2005) How can high animal diversity be supported in low productivity deserts: the role of macrodetrivory and habitat physiognomy. In: Shachak M, Gosz JR, Pickett STA, Perevolotsky A (eds) Chapter 2 in Biodiversity in Drylands: towards a unified framework. Oxford University Press, Oxford, pp. 15-29

Bayat S, Geiser F, Kristainsen P et al (2014) Organic contaminants in bats: trend and new issues. Env Inter 63:40-52

Belsky AJ, Matzke A (1999) Survey of livestock influences on stream and riparian ecosystems in the western United States. J Soil Water Cons 54:419-431

Benda P, Dietz AM et al (2008) Bats (Mammalia: Chiroptera) of the eastern mediterranean and middle east. Part 6. Bats of Sinai (Egypt) with some taxonomic, ecological and echolocation data on that fauna. Acta Soc Zool Bohem 72:1-103

Bennett BS, Thies ML (2007) Organochlorine pesticide residues in guano of Brazilian freetailed bats, Tadarida brasiliensis, Saint-Hilaire, from East Texas. B Environ Contam Tox 78:191-194

Biscardi S, Russo D, Casciani V et al (2007) Foraging requirements of the endangered longfingered bat (Myotis capaccinii): the influence of micro-habitat structure, water quality and prey type. J Zool 273:372-381

Bogan MT, Lytle DA (2011) Severe drought drives novel community trajectories in desert stream pools. Freshwater Biol 56:2070-2081

Cain DJ, Luoma SN, Carter JL et al (1992) Aquatic insects as bioindicators of trace element contamination in cobble-bottom rivers and streams. Can J Fish Aquat Sci 49:2141-2154

Calder WA (1984) Size, function and life-history. Harvard University Press, Cambridge, Massachusetts

Calvert AW (2012) Bats in riparian-restoration sites along the lower Colorado River, Arizona. Southwest Nat 57:340-342

Campbell S (2009) So long as it's near water: variable roosting behaviour of the large-footed myotis (Myotis macropus). Aust J Zool 57:89-98

Carpenter RE (1969) Structure and function of the kidney and the water balance of desert bats. Physiol Zool 42:288-302

Ciechanowski M (2002) Community structure and activity of bats (Chiroptera) over different bodies of open water. Mammal Biol 67:276-285 
Clark DR Jr, Hothem RL (1991) Mammal mortality in Arizona, California, and Nevada gold mines using cyanide extraction. Calif Fish Game 77:61-69

Clark DR Jr, Krynitsky AJ (1978) Organochlorine residues and reproduction in the little brown bat, Laurel, Maryland—June 1976. Pestic Monit J 12:113-116

Clark DR Jr, Kunz TH, Kaiser TE (1978) Insecticides applied to a nursery colony of little brown bats (Myotis lucifugus): lethal concentrations in brain tissues. J Mammal 59:84-91

Clark DR Jr, LaVal RK, Tuttle MD (1982) Estimating pesticide burdens of bats from guano analyses. Bull Environ Contam Toxicol 29:214-220

Clark DR Jr, Martin CO, Swineford DM (1975) Organochlorine insecticide residues in the freetailed bat (Tadarida brasiliensis) at Bracken Cave, Texas. J Mammal 56:429-443

Clark DR Jr, Shore RF (2001) Chiroptera. In: Shore RF, Rattner BA (eds) Ecotoxicology of wild mammals. John Wiley, Chichester, pp p159-p214

Clark DR Jr, Stafford CJ (1981) Effects of DDE and PCB (Aroclor 1260) on experimentally poisoned female little brown bats (Myotis lucifugus): lethal brain concentrations. J Toxicol Environ Health 7:925-934

Coles R (1993) Survey of bats of Uluru (Ayers Rock- Mount Olga) National Park. Final Report to the Australian National Parks and Wildlife Service, Canberra

Dahl TE, Stedman SM (2013) Status and trends of wetlands in the coastal watersheds of the Conterminous United States 2004 to 2009. U.S. Department of the Interior, Fish and Wildlife Service and National Oceanic and Atmospheric Administration, National Marine Fisheries Service, $46 \mathrm{p}$

Daniel S, Korine C, Pinshow B (2010) The use of torpor in reproductive female Hemprich's long-eared bats (Otonycteris hemprichii). Physiol Biochem Zool 183:142-148

Davidson-Watts I, Walls S, Jones G (2006) Differential habitat selection by Pipistrellus pipistrellus and Pipistrellus pygmaeus identifies distinct conservation needs for cryptic species of echolocating bats. Biol Cons 133:118-127

Davie HS, Murdoch JD, Naran NE, Ariunbold J, Batdorj S, Reading RP (2012) Bat diversity at Ikh Nart nature reserve, Mongolia. Mongolian J Biol Sciences 10:1-2

Dolch D, Batsaikhan N, Thiele K, Burger F, Scheffler I, Kiefer A, Mayer F et al (2007) Contributions to the Chiroptera of Mongolia with first evidences on species communities and ecological niches. Erforschung biologischer Ressourcen der Mongolischen Volksrepublik. In Schriftenreihe der Martin-Luther Universität Halle pp 407-458

Donato DB, Nichols O, Possingham H et al (2007) A critical review of the effects of gold cyanide-bearing tailings solutions on wildlife. Environ Int 33:974-984

Donato DB, Smith GB (2007) Australian centre for mine and environmental research project 58, Anglogold Ashanti Australia Sunrise Dam gold mine sponsor's report: summary of findings. Australian Centre for Mine and Environmental Research, Perth

Encarnação JA (2012) Spatiotemporal pattern of local sexual segregation in a tree-dwelling temperate bat Myotis daubentonii. J Ethol 30:271-278

Entwistle AC, Racey PA, Speakman JR (1997) Roost selection by the brown long-eared bat (Plecotus auritus). J Appl Ecol 34:399-408

Evenari M, Shanan L, Tadmor N (1971) The Negev: the challenge of a desert. Harvard University Press, Cambridge

Fenton MB, Morris GK (1975) Opportunistic feeding by desert bats (Myotis spp.). Can J Zool 54:526-530

Findley JS (1993) Bats: a community perspective. Cambridge University Press, Cambridge

Flaquer C, Puig-Montserrat X, Goiti U et al (2009) Habitat selection in Nathusius' pipistrelle (Pipistrellus nathusii): the importance of wetland. Acta Chiropterol 11:149-155

Flaquer C, Torre I, Ruiz-Jarillo R (2006) The value of bat-boxes in the conservation of Pipistrelluspygmaeus in wetland rice paddies. Biol Cons 128:223-230

Frampton GK, Van Den Brink PJ, Gould PJL (2000) Effects of spring drought and irrigation on farmland arthropods in southern Britain. J App Ecol 37:865-883

Frick WF, Rainey WE, Pierson ED (2007) Potential effects of environmental contamination on Yuma myotis demography and population growth. Ecol Appl 17:1213-1222 
Fujioka RS, Bonilla AJ, Rijal GK (1999) The microbial quality of a wetland reclamation facility used to produce an effluent for unrestricted non-potable reuse. Water Sci Technol 40:369-374

Geluso KN, Geluso K (2012) Effects of environmental factors on capture rates of insectivorous bats, 1971-2005. J Mammal 93:161-169

Glendell M, Vaughan N (2002) Foraging activity of bats in historic landscape parks in relation to habitat composition and park management. Anim Cons 5:309-316

Gonsalves L, Law B, Webb C, Monamy V (2012) Are vegetation interfaces important to foraging insectivorous bats in endangered coastal saltmarsh on the central coast of New South Wales? Pac Conserv Biol 18:282-292

Goodwin GN, Hawkins CP, Kershner JL (1997) Riparian restoration in the western United States: overview and perspective. Restor Ecol 5:4-14

Görföl T, Dombi I, Boldogh S et al (2009) Going further south: new data on the breeding area of Nyctalusnoctula (Schreber, 1774) in Central Europe. Hystrix It J Mamm (n.s.) 20:37-44

Greenway M (2005) The role of constructed wetlands in secondary effluent treatment and water reuse in subtropical and arid Australia. Ecol Eng 25:501-509

Greenway M, Simpson JS (1996) Artificial wetlands for wastewater treatment, water reuse and wildlife in Queensland, Australia. Water Sci Technol 33:221-229

Greenway M, Woolley A (1999) Constructed wetlands in Queensland: performance efficiency and nutrient bioaccumulation. Ecol Eng 12:39-55

Griffiths SR, Donato DB, Coulson G, Lumsden LF (2014a) High levels of activity of bats at gold mining water bodies: implications for compliance with the international cyanide management code. Environ Sci Pollut Res. doi:10.1007/s11356-014-2651-z

Griffiths SR, Donato DB, Lumsden LF, Coulson G (2014b) Hypersalinity reduces the risk of cyanide toxicosis to insectivorous bats interacting with wastewater impoundments at gold mines. Ecotox Environ Safe 99:28-34

Grindal SD, Morissette JL, Brigham RM (1999) Concentration of bat activity in riparian habitats over an elevational gradient. Can J Zool 77:972-977

Hagen EM, Sabo JL (2012) Influence of river drying and insect availability on bat activity along the San Pedro River, Arizona (USA). J Arid Environ 84:1-8

Halse SA, Ruprecht JK, Pinder AM (2003) Salinisation and prospects for biodiversity in rivers and wetlands of south-west Western Australia. Aust J Bot 51:673-688

Happold M, Happold DCD (1988) Renal form and function in relation to the ecology of bats (Chiroptera) from Malawi, Central Africa. J Zool 215:629-655

Harvey MJ, Altenbach JS, Best TL (1999) Bats of the United States. Arkansas Game and Fish Commission

IUCN 2014. The IUCN Red List of Threatened Species. Version 2014.3. $<$ http://www.iucnredlist.org >. Downloaded on 21st April 2015

Iudica CA, Bonaccorso FJ (2003) Anecdotal observations of seawater ingestion by flying foxes of the genus Pteropus (Chiroptera: Pteropodidae). Mammalia 67:455-458

Jackrel SL, Matlack RS (2010) Influence of surface area, water level and adjacent vegetation on bat use of artificial water sources. Am Midi Nat 164:74-79

Johnson JB, Gates JE, Ford WM (2008) Distribution and activity of bats at local and landscape scales within a rural-urban gradient. Urban Ecosyst 11:227-242

Kalcounis-Rueppell MC, Payne VH, Huff SR, Boyko AL (2007) Effects of wastewater treatment plant effluent on bat foraging ecology in an urban stream system. Biol Conserv 138:120-130

Kalko EKV, Schnitzler H-U (1989) The echolocation and hunting behavior of Daubenton's bat, Myotis daubentoni. Behav Ecol Sociobiol 24:225-238

Kannan K, Yun SH, Rudd RJ, Behr M (2010) High concentrations of persistent organic pollutants including PCBs, DDT, PBDEs and PFOS in little brown bats with white-nose syndrome in New York, USA. Chemosphere 80:613-618

King KA, Velasco AL, Record JA et al (2001) Contaminants in bats roosting in abandoned mines at Imperial National Wildlife Refuge, Arizona, 1998-1999. USFWS Region 2, Contaminants Program Report, $35 \mathrm{p}$ 
Kingsford RT, Thomas RF (1995) The Macquarie Marshes in arid Australia and their waterbirds: a 50-year history of decline. Environ Manage 19:867-878

Kokurewicz T (1995) Increased population of Daubenton's bat (Myotis daubentonii Kuhl, 1819) (Chiroptera: Vespertilionidae) in Poland. Myotis 32:155-161

Korine C, Pinshow B (2004) Guild structure, foraging space use, and distribution in a community of insectivorous bats in the Negev Desert. J Zool 262:187-196

Korine C, Daniel S, Pinshow B (2013) Roost selection by females Hemprich's long-eared bat. Behav Process 100:131-138

Korine C, Adams A, Shamir U, Gross A (2015) Effect of water quality on species richness and activity of desert-dwelling bats. Mamm Biol. doi:10.1016/j.mambio.2015.03.009

Krausman PR, Rosenstock SS, Cain JW III (2006) Developing waters for wildlife: science perception, values, and controversy. Wildlife Soc Bull 34:563-569

Krüger F, Harms I, Fichtner A et al (2012) High trophic similarity in the sympatric North European trawling bat species Myotis daubentonii and Myotisdasycneme. Acta Chiropterol 14:647-656

Kurta A, Kunz TH, Nagy KA (1990) Energetics and water flux of free-ranging big brown bats (Eptesicus fuscus) during pregnancy and lactation. J Mammal 71:59-65

Kusch J, Idelberger S (2005) Spatial and temporal variability of bat foraging in a western European low mountain range forest. Mammalia 69:21-33

Laegdsgaard P, McDougall A, Monamy V, Saintilan N (2004) Investigating the presence of threatened insectivorous bats on coastal NSW saltmarsh habitat. Wetlands 22:29-41

Ledger M, Edwards FK, Brown LE et al (2011) Impact of simulated drought on ecosystem biomass production: an experimental test in stream mesocosms. Glob Change Biol $17: 2288-2297$

Lewis T (1969) The diversity of the insect fauna in a hedgerow and neighbouring fields. J Appl Ecol 6:453-458

Lewis T, Stephenson JW (1966) The permeability of artificial windbreaks and the distribution of flying insects in the leeward zone. Ann Appl Biol 58:355-363

Lisón F, Calvo JF (2011) The significance of water infrastructures for the conservation of bats in a semi-arid Mediterranean landscape. Anim Cons 14:533-541

Lookingbill TR, Elmore AJ, Engelhardt KA et al (2010) Influence of wetland networks on bat activity in mixed-use landscapes. Biol Cons 143:974-983

Love JW, Taylor CM, Warren MP Jr (2008) Effects of summer drought on fish and macroinvertebrate assemblage properties in upland Ouachita Mountain Streams, USA. Am Mid Nat 160:265-277

Lovegrove BG (2000) The zoogeography of mammalian basal metabolic rate. Am Nat 156:201-219

Lučan RK, Radil J (2010) Variability of foraging and roosting activities in adult females of Daubenton's bat (Myotis daubentonii) in different seasons. Biologia 65:1072-1080

Lumsden IF, Bennett AF (1995) Bats of a semi-arid environment in south-eastern Australia: biogeography, ecology and conservation. Wildlife Res 22:217-239

Mackey RL, Barclay RMR (1989) The influence of physical clutter and noise on the activity of bats over water. Can J Zool 67:1167-1170

Mares MA (1992) Neotropical mammals and the myth of Amazonian biodiversity. Science 255:976-979

Marom S, Korine C, Wojciechowski MS et al (2006) Energy metabolism and evaporative water loss in the European free-tailed bat and Hemprich's long-eared bat (Microchiroptera): species sympatric in the Negev. Physiol Biochem Zool 79:944-956

McCain CM (2007) Could temperature and water availability drive elevational species richness patterns? A global case study for bats. Global Ecol Biogeogr 16:1-13

McKenzie NL, Burbidge AA, Baynes A, Brereton RN, Dickman CR, Gordon G, Gibson LA, Menkhorst PW, Robinson AC, Williams MR, Woinarski JCZ (2007) Analysis of factors implicated in the recent decline of Australia's mammal fauna. J Biogeogr 34:597-611 
Mendelssohn H, Yom-Tov Y (1999) A report of birds and mammals which have increased their distribution and abundance in Israel due to human activity. Isr J Zool 45:35-47

Menzie CA (1980) Potential significance of insects in the removal of contaminants from aquatic systems. Water Air Soil Pollut 13:473-479

Mickeviciene I, Mickevicius E (2001) The importance of various habitat types to bats (Chiroptera: Vespertilionidae) in Lithuania during the summer period. Acta Zool Lituanica $11: 3-14$

Mispagel C, Allinson M, Allinson G, Iseki N, Grant C, Morita M (2004) DDT and metabolites residues in the southern bent-wing bat (Miniopterus schreibersii bassanii) of south-eastern Australia. Chemosphere 55:997-1003

Monadjem A, Reside A (2008) The influence of riparian vegetation on the distribution and abundance of bats in an African savannah. Acta Chiropterol 10:339-348

Monamy V, Taylor JE, Gonsalves L, Ellis MV (2013) Bassian bats in the Eyrean sub-region? Preliminary acoustic data from the Bogan and Macquarie Rivers in semi-arid NSW. Aust J Zool 36:461-469

Morton SR, Short J, Barker RD (1995) Refugia for biological diversity in arid and semi-arid Australia. Environment Australia, Biodiversity Unit, Canberra

Naicker K, Cukrowska E, McCarthy TS (2003) Acid mine drainage arising from gold mining activity in Johannesburg, South Africa and environs. Environ Pollut 122:29-40

Naidoo S, Mackey RL, Schoeman MC (2011) Foraging ecology of insectivorous bats at a polluted and an unpolluted river in an urban landscape. Durban Mus Novit 34:21-28

Naidoo S, Vosloo D, Schoeman MC (2013) Foraging at wastewater treatment works increases the potential for metal accumulation in an urban adapter, the banana bat (Neoromicia nana). Afri Zool 48:39-55

Naidoo S, Vosloo D, Schoeman MC (2014) Haematological and genotoxic responses in an urban adapter, the banana bat, foraging at wastewater treatment works. Ecotox Env Safe 114:304-311

Nicholls B, Racey PA (2006) Habitat selection as a mechanism of resource partitioning in two cryptic bat species Pipistrellus pipistrellus and Pipistrellus pygmaeus. Ecography 29:697-708

Nickerson Z, O'Keefe (2013) Bats and pools: assessing how bats use pools across North America. http://www.batsandpools.wordpress.com

Nicolet P, Biggs J, Fox G et al (2004) The wetland plant and macroinvertebrate assemblages of temporary ponds in England and Wales. Biol Cons 120:261-278

Nilsson C, Berggren K (2000) Alterations of riparian ecosystems caused by river regulation. BioSci 50:783-792

Noy-Meir I (1973) Desert ecosystems: environments and producers. Ann Rev Ecol Syst 4:25-51

Nyambayar B, Ariunbold J, Sukhchuluun G (2010) A contribution to the bats inhabiting arid steppe habitats in central Mongolia. Erforsch Biol Ress Mongolei 11:329-340

Oakeley SF, Jones G (1998) Habitat around maternity roosts of the $55 \mathrm{kHz}$ phonic type of pipistrelle bats (Pipistrellus pipistrellus). J Zool 245:222-228

O'Brien CS, Waddell RB, Rosenstock SS, Rabe MJ (2006) Wildlife use of water catchments in southwestern Arizona. Wildlife Soc Bull 34:582-591

Ojeda RA, Tabeni S (2009) The mammals of the Monte Desert revisited. J Arid Environ 73:173-181

Olade MA (1987) Heavy metal pollution and the need for monitoring: illustrated for developing countries in West Africa. In: Hutchinson TC, Meema KM (eds) Lead, mercury, cadmium and arsenic in the environment. Wiley, New York, pp 335-341

O'Shea TJ, Ellison LE, Neubaum DJ et al (2010) Recruitment in a Colorado population of big brown bats: breeding probabilities, litter size, and first-year survival. J Mammal 91:418-442

O'Shea TJ, Everette AL, Ellison LE (2001) Cyclodiene insecticide, DDE, DDT, Arsenic, and Mercury contamination of big brown bats (Eptesicus fuscus) foraging at a Colorado Superfund site. Arch Environ Contam Toxicol 40:112-120 
Papadatou E, Butlin RK, Altringham JD (2008) Seasonal roosting habits and population structure of the long-fingered bat Myotis capaccinii in Greece. J Mammal 89:503-512

Park KJ, Cristinacce A (2006) The use of sewage treatment works as foraging sites by insectivorous bats. Anim Cons 9:259-268

Park KJ, Muller CT, Markman S et al (2009) Detection of endocrine disrupting chemicals in aerial invertebrates at sewage treatment works. Chemosphere 77:1459-1464

Parsons KN, Jones G (2003) Dispersion and habitat use by Myotis daubentonii and Myotis nattereri during the swarming season: implications for conservation. Anim Cons 6:283-290

Petit MG (2007) A chronolocal record of environmental chemical from analysis /of stratified vertebrate excretion deposition in a sheltered environment. Env Res 6:339-343

Pikula J, Zukal J, Adam V et al (2010) Heavy metals and metallothionein in vespertilionid bats foraging over aquatic habitats in the Czech Republic. Environ Toxicol Chem 29:501-506

Pilosof S, Korine C, Moore M, Krasnov B (2013) Sewage-water contamination alters immune response in a desert bat. Mamm Biol 79:183-188

Polak T, Korine C, Yair S, Holderied MW (2011) Differential effects of artificial lighting on flight and foraging behaviour of two sympatric bat species in a desert. J Zool 285:21-27

Puckridge JT, Sheldon F, Walker KF, Boulton AJ (1998) Flow variability and the ecology of large rivers. Mar Freshwater Res 49:55-72

Racey P (1998) The importance of the riparian environment as a habitat for British bats. Symp Zool Soc Lond 71:69-91

Rachwald A (1992) Habitat preference and activity of the noctule bat Nyctalusnoctula in the Białowieża Primeval Forest. Acta Theriol 37:413-422

Rainey WE, Power ME, Clinton SM (2006) Temporal and spatial variation in aquatic insect emergence and bat activity in a restored floodplain wetland. Final Report to CALFED

Rainho A, Palmeirim JM (2011) The importance of distance to resources in the spatial modelling of bat foraging habitat. PLoS ONE 6(4):e19227

Rautenbach IL, Whiting MJ, Fenton MB (1996) Bats in riverine forests and woodlands: a latitudinal transect in southern Africa. Can J Zool 74:312-322

Razgour O, Korine C, Saltz D (2010) Pond characteristics as determinants of diversity and community structure in desert bats. Anim Cons 13:505-513

Razgour O, Korine C, Saltz D (2011) Does interspecific competition drive patterns of habitat use in desert bat communities? Oecologia 167:493-502

Read J (1998) Vertebrate fauna of the Nifty mine site, Great Sandy Desert, with comments on the impacts of mining and rehabilitation. West Aust Nat 22:1-22

Rebelo H, Rainho A (2009) Bat conservation and large dams: spatial changes in habitat use caused by Europe's largest reservoir. Endang Species Res 8:61-68

Reidinger, RF Jr (1972) Factors influencing Arizona bat population levels. Unpublished Ph.D. dissertation Univ. Arizona, Tucson. $172 \mathrm{p}$

Reidinger RF Jr, Cockrum EL (1978) Organochlorine residues in free-tailed bats (Tadarida brasiliensis) at Eagle Creek Cave, Greenlee County, Arizona. In: Olembo RJ, Castelino JB, Mutere FA (eds) Proceedings of the 4th international bat research conference, Kenya Literature Bureau, Nairobi (pp 85-96)

Reinhold JO, Hendriks AJ, Slager LK et al (1999) Transfer of microcontaminants from sediment to chironomids, and the risk for the Pond bat Myotis dasycneme (Chiroptera) preying on them. Aquat Ecol 33:363-376

Rhodes M (2007) Roost fidelity and fission-fusion dynamics of white-striped free-tailed bats (Tadarida australis). J Mammal 88:1252-1260

Rogers DS, Belk MC, González MW et al (2006) Patterns of habitat use by bats along a riparian corridor in northeastern Utah. Southwest Nat 51:52-58

Roshier DA, Whetton PH, Allan RJ, Robertson AI (2001) Distribution and persistence of temporary wetland habitats in arid Australia in relation to climate. Austral Ecol 26:371-384

Runck C (2007) Macroinvertebrate production and food web energetics in an industrially contaminated stream. Ecol Appl 17:740-753 
Russo D, Cistrone L, Garonna AP et al (2010) Reconsidering the importance of harvested forests for the conservation of tree-dwelling bats. Biodivers Cons 9:2501-2515

Russo D, Cistrone L, Jones G (2012) Sensory ecology of water detection by bats: a field experiment. PLoS ONE 7(10):e48144

Russo D, Jones G (2003) Use of foraging habitats by bats in a Mediterranean area determined by acoustic surveys: conservation implications. Ecography 26:197-209

Russo D, Jones G, Migliozzi A (2002) Habitat selection by the Mediterranean horseshoe bat, Rhinolophus euryale (Chiroptera: Rhinolophidae) in a rural area of southern Italy and implications for conservation. Biol Cons 107:71-81

Rydell J, Bushby A, Cosgrove CC, Racey PA (1994) Habitat use by bats along rivers in northeast Scotland. Folia Zool 43:417-424

Rydell J, Miller LA, Jensen ME (1999) Echolocation constraints of Daubenton's bat foraging over water. Funct Ecol 13:247-255

Salsamendi E, Garin I, Arostegui I et al (2012) What mechanism of niche segregation allows the coexistence of sympatric sibling rhinolophid bats? Front Zool 9:30

Sandoval ML, Barquez RM (2013) The Chacoan bat fauna identity: patterns of distributional congruence and conservation implications. Revista Chilena de Historia Natural 86:75-94

Sandoval ML, Szumik CA, Barquez RM (2010) Bats and marsupials as indicators of endemism in the Yungas forest of Argentina. Dongwuxue Yanjiu 31:633-644

Sattler T, Bontadina F, Hirzel A et al (2007) Ecological niche modelling of two cryptic bat species calls for a reassessment of their conservation status. J Appl Ecol 44:1188-1199

Saunders DA, Wintle BA, Mawson PR, Dawson R (2013) Egg-laying and rainfall synchrony in an endangered bird species: Implications for conservation in a changing climate. Biol Conserv 161:1-9

Schoeman CM, Jacobs DS (2003) Support for the allotonic frequency hypothesis in an insectivorous bat community. Oecologia 134:154-162

Schoeman CM, Jacobs DS (2011) The relative influence of competition and prey defences on the trophic structure of animalivorous bat ensembles. Oecologia 166:493-506

Schwartz SS, Jenkins DG (2000) Temporary aquatic habitats: constraints and opportunities. Aquat Ecol 34:3-8

Scott SJ, McLaren G, Jones G et al (2010) The impact of riparian habitat quality on the foraging and activity of pipistrelle bats (Pipistrellus spp.). J Zool 280:371-378

Seibold S, Buchner J, Bässler C, Müller J (2013) Ponds in acidic mountains are more important for bats in providing drinking water than insect prey. J Zool 290:302-308

Serra-Cobo J, López-Roig M, Marques-Bonet T et al (2000) Rivers as possible land-marks in the orientation flight of Miniopteruss chreibersii. Acta Theriol 45:347-352

Shabalala AN, Combrinck L, McCrindle R (2013) Effect of farming activities on seasonal variation of water quality of Bonsma Dam, KwaZulu-Natal. S Afri J Sci 109:01-07

Sherwin HA, Montgomery WI, Lundy MG (2013) The impact and implications of climate change for bats. Mamm Rev 43:171-182

Siemers B, Schnitzler HU (2004) Echolocation signals reflect niche differentiation in five sympatric bat species. Nature 429:657-658

Siemers BM, Stilz P, Schnitzler H-U (2001) The acoustic advantage of hunting at low heights above water: behavioural experiments on the European 'trawling' bats Myotis capaccinii, $M$. dasycneme and M. daubentonii. J Exp Bio 204:3843-3854

Sirami C, Jacobs DS, Cumming GS (2013) Artificial wetlands and surrounding habitats provide important foraging habitat for bats in agricultural landscapes in the Western Cape, South Africa. Biol Cons 164:30-38

Smith DB, Donato DB, Griffiths SR, Gillespie CG, Rowntree J (2008) Ecology of a goldmining tailings facility in the Eastern Goldfields of Western Australia: a case study. Int J Min Reclam Environ 22:154-173

Speakman JR, Racey PA, Catto CC et al (1991) Minimum summer populations and densities of bats in N. E. Scotland, near the borders of their distributions. J Zool 225:327-345 
Stechert C, Kolb M, Bahadir M, Djossa BA, Fahr J (2014) Insecticide residues in bats along a land use-gradient dominated by cotton cultivation in northern Benin, West Africa. Environ Sci Pollut R 21:8812-8821

Stoffberg SM, Jacobs DS, Mackie IJ, Matthee CA (2010) Molecular phylogenetics and historical biogeography of Rhinolophus bats. Mol Phylogenet Evol 54:1-9

Swanepoel RE, Racey PA, Shore RF et al (1999) Energetic effects of sublethal exposure to lindane on pipistrelle bats (Pipistrellus pipistrellus). Environ Poll 104:169-177

Syaripuddin K, Kumar A, Sing K W, Halim MRA, Nursyereen MN, Wilson JJ (2014) Mercury accumulation in bats near hydroelectric reservoirs in Peninsular Malaysia. Ecotoxicology 23:1164-1171

Thomas DW, Fenton MB (1978) Notes on the dry season roosting and foraging behaviour of Epomophorous gambianus and Roussettus aegyptiacus (Chiroptera: Pteropodidae). J Zool 186:403-406

Timms BV (2005) Salt lakes in Australia: present problems and prognosis for the future. Hydrobiologia 552:1-15

Tuttle SR, Chambers CL, Theimer TC (2006) Potential effects of livestock water-troughs modifications on bats in Northern Arizona. Wildlife Soc Bull 34:602-608

UNESCO (1979) Map of the World Distribution of Arid Regions. UNESCO, Paris

Vaughan N, Jones G, Harris S (1996) Effects of sewage effluent on the activity of bats (Chiroptera: Vespertilionidae) foraging along rivers. Biol Cons 78:337-343

Vaughan N, Jones G, Harris S (1997) Habitat use by bats (Chiroptera) assessed by means of a broad-band acoustic method. J Appl Ecol 34:716-730

von Frenckell B, Barclay RMR (1987) Bat activity over calm and turbulent water. Can J Zool 65:219-222

Walker KF (1985) A review of the ecological effects of river regulation in Australia. In: Davies BR, Walmsley RD (eds) Perspectives in Southern Hemisphere Limnology. Springer Netherlands, pp. 111-129

Walsh AL, Harris S, Hutson AM (1995) Abundance and habitat selection of foraging vespertilionid bats in Britain: a landscape-scale approach. Symp Zoo Soc Lond 67:325-344

Walters DM, Fritz KM, Otter RR (2008) The dark side of subsidies: adult stream insects export organic contaminants to riparian predators. Ecol Appl 18:1835-1841

Warren RD, Water DA, Altringham JD et al (2000) The distribution of Daubenton's bats (Myotis daubentonii) and pipistrelle bats (Pipistrellu spipistrellus) (Vespertilionidae) in relation to small-scale variation in riverine habitat. Biol Cons 92:85-91

Webb PI (1995) The comparative ecophysiology of water balance in micro-chiropteran bats. In: Racey PA Swift SM (eds) Ecology, evolution and behaviour of bats. Oxford University Press, Oxford, pp 203-218

Webb PI, Speakman JR, Racey PA (1995) Evaporative water loss in two sympatric species of vespertilionid bat, Plecotus auritus and Myotis daubentoni: relation to foraging mode and implications for roost site selection. J Zool 235:269-278

Williams AJ, Dickman CR (2004) The ecology of insectivorous bats in the Simpson Desert central Australia: habitat use. Aust Mammal 26:205-214

Williams WD (1981) Running water ecology in Australia. In: Lock MA, Dudley D (eds) Perspectives in Running Water Ecology. Springer US, pp. 367-392

Williams JA, O'Farrell MJ, Riddke BR (2006) Habitat use by bats in a riparian corridor of the Mojave desert in southern Nevada. J Mammal 87:1145-1153

Yom-Tov Y (1993) Character displacement among the insectivorous bats of the Dead Sea area. J Zool 230:347-356

Yom-Tov Y, Mendelssohn H (1988) Changes in the distribution and abundance of vertebrates in Israel during the 20th century. In: Tchernov E, Yom-Tov Y (eds) The zoogeography of Israel. Dr. W. Junk, Dordrecht, pp 515-547

Young RA, Ford GI (2000) Bat fauna of a semi-arid environment in central western Queensland, Australia. Wildlife Res 27:203-215 